\title{
The Impact of the Pandemic Covid-19 on the Human Right to Freedom of Movement
}

\author{
By Valentyn Zolka ${ }^{1}$, Olha Tsarenko ${ }^{2}$, Iryna Kushnir ${ }^{3}$, Serhii Tsarenko ${ }^{4}$, \\ Roman Havrik ${ }^{5}$
}

\begin{abstract}
The article discusses the impact of the pandemic COVID-19 on the human rights, in particular, the right to freedom of movement and free choice of residence. The purpose of the article is to investigate whether the restrictions implemented to prevent spread of the infection were legitimate and necessary. The concept and content of the right to free movement according to Ukrainian legislation has been investigated. The legitimate grounds for restriction of human rights were analyzed. The state of compliance of Ukrainian legislation with the legislation of the EU and world standards was revealed. The range of issues that Ukraine faced during the pandemic COVID-19 and limitations of human rights were disclosed. Particular attention was paid to legal acts which implemented such limitations. It was revealed that the approach of the Ukrainian legislator while implementing restrictions of human rights was unconstitutional and violated fundamental human freedoms. General and special scientific methods were used in the process of research, such as dialectical, comparative, dogmatic and legal methods.
\end{abstract}

Keywords: pandemic, COVID-19, coronavirus, right to freedom of movement, right to free choice of residence, buman rights

\section{Introduction}

In today's society, the mobility of the world's population is growing every year, the movement of people is becoming more and more widespread, the migration of workers is constantly increasing. This requires states and international organizations to properly and timely regulate such processes. At the same time, the realities of today, due to the spread of COVID-19 and the restrictions imposed in this regard, necessitate the study of the right to freedom of movement in the light of new conditions.

It is obvious that the right to freedom of movement has a special legal nature. Public relations regarding freedom of movement are subject to legal regulation by various branches of law (both private and public). We can talk about the intersectional legal nature of regulating the process of exercising and protecting the right to freedom of movement.

| ${ }^{1}$ Doctor of Legal Sciences, Associate Professor, Head of the Department of Constitutional, Administrative and International Law of the National Academy of the State Border Guard Service of Ukraine

2Ph.D., Associate Professor of the Department of Constitutional, Administrative and International law of the National Academy of the State Border Guard Service of Ukraine

3Ph.D., Doctoral Candidate of Higher Doctorate of the National Academy of the State Border Guard Service of Ukraine

${ }^{4}$ Ph.D., Associate Professor of the Department of Theory and History of the State and Law and Private-Law Disciplines of the National Academy of the State Border Guard Service of Ukraine

5Ph.D., Associate Professor of the Department of Constitutional, Administrative and International Law of the

National Academy of the State Border Guard Service of Ukraine 
In Ukraine, the fundamental norm for the legal regulation of freedom of movement is Article 33 of the Constitution of Ukraine, according to which all people have the right to freedom of movement and the right to choose the place of residence freely, as well as the possibility to leave Ukraine whenever they want, except some restrictions established by law. No one who has the citizenship of Ukraine can be deprived of the possibility to come back to Ukraine at any time. It should be emphasized that according to Art. 21 of the Ukrainian Constitution, the right to freedom of movement belong to a person from birth, and therefore are considered inalienable and inviolable rights.

However, the state and the law have to not only recognize human freedom, but also ensure such freedom. This includes its restriction to the necessary extent, so that all other actors can also exercise it without hindrance. This also applies to freedom of movement and the right to choose the place of residence freely, which are fundamental human freedoms.

The freedom in question has a wide range of action, which makes it possible to study it in at least two planes. The first is related to respect for human dignity and the provision of appropriate conditions for the development of one's personality. It should be borne in mind, however, that a significant impact on the development of personality has an active contact of the individual with the environment, i.e. with knowledge of the world, the development of interests, gaining experience.

The second plane, which expresses the content of freedom of movement, is related to the knowledge of different cultures and customs, exchange of experiences between peoples, which is a condition of cultural progress and civilization, and therefore associated with maintaining peace and developing international cooperation. However, this inalienable right to freedom of movement and free choice of residence may be restricted under certain conditions and grounds. The main international legal instruments concerning human rights provide for the restriction of this right of a general nature, in particular, during war or the imposition of a state of emergency in the country, as well as in other cases provided by law.

In Ukraine, as in other countries, the right to freedom of movement has been significantly restricted since the announcement of the COVID-19 coronavirus pandemic. This was especially noticeable since March 2020, when the quarantine measures has been implemented to prevent the spread of the infection. Numerous prohibitions, including freedom of movement, were introduced with the adoption of the Resolution of the Cabinet of Ministers of Ukraine "On prevention of the spread of coronavirus COVID-19 in Ukraine" dated March 11, 2020 (Cabinet of Ministers of Ukraine, 2020).

However, in Ukraine, the implemented restrictions has led to violation of some constitutional rights, in particular, the right of citizens to freedom of movement and the prohibition for certain categories to move across the state border and checkpoints, the abolition of transport links between cities, and so on.

Despite the objective necessity of such measures, in such a situation state intervention should be measured thoroughly to not violate human rights.

\section{The Concept and Content of the Right to Freedom of Movement}

The right to freedom of movement is one of the basic human rights, the legal regulation of which gets much attention in international regulations, as well as in the 
national legislation of European countries and in Ukraine (Vansweevelt \& Dewallens, 2020). Now for most people the right to free movement seems so natural and inalienable that they do not even think about its meaning, and the importance and fundamentality of this right becomes clear only when the individual is faced with the potential loss of this right (Wilhelm, 2010).

The normative definition of the concept of "freedom of movement" is given in Part 2 of Art. 3 of the Law "On Freedom of Movement and Free Choice of Residence" (Verkhovna Rada, 2003), according to which freedom of movement is the right to move freely and unhindered at will in Ukraine, except some cases provided by law.

Analyzing the definition of freedom of movement enshrined in the mentioned Law, we can say, that it would be better not to use the term "relocation" in it, because in studies on freedom of movement conducted by the UN Commission on Human Rights, the term "relocation" is used to describe acts of violence (Anisimova, 2005).

S. Chekhovich also emphasizes the terminological ambiguity in consolidating the right to freedom of movement. In particular, he points to the need to clarify Part 2 of Art. 33 of the Criminal Code of Ukraine, according to which a citizen of Ukraine cannot be deprived of the possibility to come back to Ukraine whenever he or she wants to. He notes that in international legal acts, in particular in paragraph 4 of Art. 12 of the International Covenant on Civil and Political Rights of December 19, 1996 (United Nations, 1996), it is stipulated that no one may be deprived of the right to enter his or her own country, i.e. it is not a question of return but of entry. Accordingly, in order to bring in line with international legal standards, the second part of Article 33 of the Criminal Code of Ukraine, he proposes to state as follows: "A citizen of Ukraine may not be deprived of the right to enter at any time on the territory of Ukraine" (Chekhovich, 2008).

According to the Law of Ukraine "On the Procedure for Leaving Ukraine and Entering Ukraine by Ukrainian Citizens" (Verkhovna Rada, 1994), a Ukrainian citizen may not be restricted in his or her right to enter Ukraine under any circumstances. As for the right of departure of citizens of Ukraine from the territory of Ukraine, Art. 6 of the mentioned Law provides an exclusive list of grounds for temporary restrictions on the right of Ukrainian citizens to travel abroad.

The documents that give the right to leave and enter Ukraine as well as confirm the identity of a Ukrainian citizen during their stay abroad are:

- passport of a Ukrainian citizen for travel abroad;

- travel document of the child;

- diplomatic passport;

- service passport;

- seaman's identity card. These documents are the property of Ukraine and, provided they are properly executed, are valid for travel to all countries of the world.

A passport of a Ukrainian citizen for travel abroad is a document certifying the identity of a person when crossing the state border of Ukraine and staying abroad. Passports are issued to those who are 18 years old and permanently reside in Ukraine. In exceptional cases, the passport may be issued before the citizen reaches the age of 18 .

According to the Law of Ukraine "On Border Control" of November 5, 2009 (Verkhovna Rada, 2009), border control is carried out on persons crossing the state border in order to counteract illegal movement of persons across the state border, illegal migration, human 
trafficking, as well as illegal movement of weapons, drugs and psychotropic substances and precursors, ammunition, explosives, materials and items prohibited for movement across the state border.

The right to leave the territory of the state cannot be conditioned by the presence of any specific purpose (tourism, business, education, treatment, etc.) or the period during which the individual wishes to be outside the territory of the state. This provision covers both travel abroad and final emigration from the country. In order for a person to be able to exercise this right in relation to the state of residence and the state of citizenship, certain obligations are introduced (Baranov, Kozlyuk \& Vashkevich, 2015).

As follows from the definition of the right to freedom of movement given in the Law of Ukraine "On Freedom of Movement", this right extends to the entire territory of Ukraine, which is separated from the territory of other countries by the state border (Anisimova, 2005). According to Art. 1 of the Law of Ukraine "On the State Border of Ukraine" dated November 4, 1991 (Verkhovna Rada, 1991), the state border of Ukraine is a line and a vertical surface passing along this line, which define the boundaries of the territory of Ukraine - land, water, subsoil, airspace. However, today part of the territory of Ukraine is under temporary occupation or temporarily not controlled by public authorities and local governments, so it is clear that in these territories can not be implemented the same order of freedom of movement as in the rest of Ukraine.

Thus, the right to freedom of movement in the legislation of Ukraine is understood in three areas:

- the right to move freely within the territory of Ukraine;

- the right to leave the territory of Ukraine freely;

- the right of citizens of Ukraine to return to Ukraine whenever they want.

The freedom of movement is inextricably linked with the criterion of legality of stay, which plays a leading role in the ability of a person to move freely (Jabłoński, 2014).

For citizens of Ukraine, the legal grounds for staying on the territory of Ukraine are belonging to the citizenship of Ukraine. That is, a citizen of Ukraine has legal grounds to be on the territory of Ukraine as long as he or she has the citizenship of Ukraine (Chekhovich, 2003). This follows from the content of citizenship, as a legal relationship between a person and the state, which is manifested in mutual rights and responsibilities, as well as based on the provisions of Art. 25 and Art. 33 of the Criminal Code of Ukraine, according to which a citizen of Ukraine cannot be expelled from Ukraine or extradited to another state and cannot be deprived of the right to return to Ukraine at any time. Legal grounds for stay on the territory of Ukraine for foreigners and stateless persons are established by Art. 4 of the Law of Ukraine "On the legal status of foreigners and stateless persons" of September 11, 2011 (Verkhovna Rada, 2011). This article has seventeen points that determine the legality of the stay of different categories of foreigners in Ukraine. In general, this article, in our opinion, is not very well formulated, because there are only three legal grounds for the stay of foreigners in Ukraine:

- permanent residence permit;

- temporary residence permit;

- visa.

Legality of stay on the territory of the country is determined by the precondition of realization of the right to freedom of movement also in Art. 12 of the International 
Covenant on Civil and Political Rights. As the practice of the European Court of Human Rights (hereinafter - the ECtHR) shows, the state has the right to independently establish rules that determine the criteria for the legality of the stay of foreigners in the country (Litins'ka \& Karpenko, 2020). In case of violation of the established rules, the loss of the status of legal stay is possible, which may entail the loss of freedom of movement (Sukhanova, 2009). That is, it is national law and public authorities that determine the requirements that a person's stay must meet in order to be recognized as lawful (Vasilieva, 2010).

This means that if the citizens of Ukraine do not need to fulfill any additional conditions and requirements to exercise the right to freedom of movement in their country, foreigners can exercise this right only if the conditions set by law regarding the legality of their stay in the country are met.

The main features of the exercise of the right to freedom of movement by foreigners are the establishment of a number of additional restrictions on their freedom of movement in certain territories and in respect of certain categories of foreigners.

There are different approaches to scientific definition of the concept of "freedom of movement". Thus, R. Stefanchuk defines the right to freedom of movement as a personal non-property right of an individual, which provides an individual with the opportunity to move on the territory of Ukraine freely in any direction and at any time, except for restrictions established by law, as well as to move freely outside the borders of Ukraine and return to Ukraine without hindrance (Stefanchuk, 2008). However, in our opinion, this definition is not very successful, because the freedom to return to Ukraine is absolute for citizens of Ukraine and does not apply to: stateless persons who were not born in Ukraine, but are legally permanently resident in Ukraine; foreigners who were not born in Ukraine, but have been legally on its territory for a long time; persons (foreigners and stateless persons) who were born in Ukraine but do not have the citizenship of Ukraine. That is, this definition does not take into account such individuals as foreigners and stateless persons.

O. Dynko suggests understanding freedom of movement in narrow and broad senses. In the narrow sense, in his opinion, it is a constitutional and legal category, which consists in the individual's choice of the option of any movement. Freedom of movement in the broadest sense, in addition to movement, includes free choice of residence within the state, the right to freely leave the territory of the state, the right to return to the state of citizenship or permanent residence (Dynko, 2003).

The question of whether these opportunities for free movement apply to human rights or freedoms remains ambiguous. To find out, whether the freedom of movement belongs to the category of rights or freedoms, it is first necessary to understand some general aspects of the relationship between "rights" and "freedoms". In general, this issue in legal science remains controversial. Some scholars believe that the Constitution does not regulate or establish freedom, it is provided there only indirectly and, above all, through the institution of fundamental rights that bind the state to constitutional obligations. Therefore in the science of constitutional law it is more appropriate not to talk about "rights and freedoms" (Muchnik, 2003).

Other scholars note that the term "freedom" is intended to emphasize the wider possibilities of individual choice, without outlining its specific outcome, and the term 
"right" defines specific human actions. By their legal nature and the system of guarantees rights and freedoms are identical, respectively, the distinction between them is difficult, and differences in terminology are more traditional than fundamental (Lukasheva, 2001). The ability to move freely, some scientists attribute to human freedoms, not rights. Thus, V. Pogorilko note that human rights can be exercised, as a rule, in the presence of certain legal means, "mechanisms". For example, the right to work, the right to social security and some other constitutional rights cannot be exercised without a proper legal procedure established by the state. Human freedoms as opportunities based on the most free selfdetermination of a person (for example, freedom of movement, freedom of thought and speech, free expression of views and beliefs) can usually be exercised without such assistance (Pogorilko, 2006). Thus, freedom of movement belongs to the category of freedoms on the grounds that this possibility can be exercised without the assistance of the state.

We can only partially agree with this statement. In our opinion, the possibility to move freely "without the appropriate legal procedure established by the state" applies only to part of the mentioned possibility, namely: the freedom of movement of citizens throughout the country. As for such an aspect of this phenomenon as the possibility to leave the territory of Ukraine freely, in accordance with national legislation and international regulations, to implement this possibility should follow a number of established procedures (obtain a visa, insurance, have sufficient financial security, etc.). Therefore, taking into account the above, we support the view that to characterize the opportunities enshrined in Part 1 of Art. 33 of the Constitution of Ukraine, it is advisable to use the term "right" and not "freedom" (Anisimova, 2005). Thus, the right to freedom of movement (right to free movement) is the right guaranteed by the Constitution of Ukraine and international legal acts, to move on the territory of Ukraine in any direction freely and without the need to obtain any special permits, in any way, at any time, as well as to leave the territory of Ukraine, except for restrictions established exclusively by law.

\section{Legitimate Grounds for Restricting the Right to Freedom of Movement}

Art. 12 of the International Covenant on Civil and Political Rights explicitly provides for restrictions on freedom of movement. However, the application of such restrictions requires a threat to public security, public order, public health or morals, or the rights and freedoms of others.

It should be borne in mind that these restrictions are exhaustive and no other restrictions are inadmissible, and the restrictions provided for by national law and existing in practice must not go beyond these limits (Article 5 of the International Covenant on Civil and Political Rights). Unfortunately, in practice, States do not yet adhere to this basic principle. Restriction of freedom of movement is also provided by Art. 2 of Protocol № 4 to the Convention for the Protection of Human Rights and Fundamental Freedoms (Council of Europe, 1968). The exercise of the right to freedom of movement and choice of residence may not be subject to any restrictions other than those provided by law and necessary in a democratic society in the interests of national or public security, public order, crime prevention, health protection or morality or to protect the rights and freedoms of others. Ukrainian law also provides for the possibility of restricting human rights, in particular the 
right to freedom of movement. Article 34 of the Constitution of Ukraine states that the exercise of enshrined rights and freedoms may be restricted by law only in the interests of public order, health and morals of the population or protection of the rights and freedoms of others, which fully complies with international standards.

Therefore, restrictions on freedom of movement and free choice of residence can be imposed both on the status of a person and on the territory.

In particular, Art. 13 of the Law of Ukraine "On Freedom of Movement and Free Choice of Residence in Ukraine" stipulates that free choice of place of residence is limited in the next administrative-territorial units:

- in the border zone;

- on the territories of military facilities;

- in zones which, according to the law, belong to zones with limited access;

- in the territory where in case of danger of spread of infectious diseases and poisonings of people special conditions are implemented;

- in the territories where martial law or state of emergency has been imposed;

- in the temporarily occupied territories.

This law also regulates the restriction of free choice of place of residence in respect of:

- persons under 14 years of age;

- persons to whom, in accordance with procedural law, precautionary measures related to restriction or imprisonment have been applied;

- persons serving a sentence of imprisonment or restriction of liberty by a court sentence;

- persons who, in accordance with the law, are under administrative supervision;

- persons who are subjects to involuntary hospitalization and treatment in accordance with the legislation on infectious diseases and psychiatric care;

- foreigners and stateless persons who do not have legal grounds to stay on the territory of Ukraine.

With regard to specific types of restrictions, in almost all countries, national security is a limiting factor in exercising the right to leave the country. This right is limited over time even by making a special mark on passports by certain countries, which excludes the right to enter other countries. However, in our opinion, such a restriction is too broad and arbitrary if it applies to all citizens, regardless of how well informed they are on issues directly related to state security.

It should be noted that considerations relating to the maintenance of public order may be used against persons seeking to evade their legal obligations to pay taxes, public or military service. In order not to use restrictions against criminals rather than political opponents, it must be based on a precise definition of "public order". Such restrictive measures provide for the forced residence of the persons concerned in a particular place and allow for the existence of various other restrictions.

The state may impose restrictions on its territory, taking into account the interests of public health and morals related to access to water supply or contaminated areas.

In this aspect, there are restrictions at the legislative level in Ukraine that contradict international standards. Thus, the rules of Art. 29 of the Law of Ukraine "On ensuring the sanitary and epidemiological well-being of the population" of February 24, 1994 (Verkhovna Rada, 1994) allow to Ukrainian citizens from countries (localities) where particularly dangerous infectious diseases are registered, to entry into the territory of 
Ukraine only on the basis of documents provided by international agreements and sanitary legislation of Ukraine.

Although the list of restrictions is exhaustive, in practice there are other forms of restrictions.

First, the restrictions are admissible in the interests of the state. The decision on what is in the interests of the state is made at the discretion of the executive, and the courts review such a decision only in some cases.

Second, the economic and social conditions in the country directly affect the possibility of exercising the right to leave the country and return to it.

Third, administrative restrictions, in particular passport procedures or their absence, give the executive the discretion to issue, seize or refuse to issue travel documents without any additional controls.

Fourth, the threat of deprivation of citizenship for the purpose of punishing those seeking to exercise their right to leave the country is an abuse that deprives the applicant of the right to leave the country and prevents him from applying for emigration or even temporary departure.

Fifth, there are restrictions on going abroad, which are stricter for people of working age than those who have reached the age of 60 and are no longer productive workers. The authorities of such states do not prevent such persons from staying abroad and, for the most part, even facilitate their emigration. In other cases, even elderly and sick applicants whose children are abroad are not allowed to reunite with their families.

Sixth, in most states, persons incapable of issuing travel documents and exercising the right to leave the country are denied, unless such persons obtain the consent of the guardian, and they should not be used against married women.

Finally, the deprivation of persons seeking to exercise their right to leave the country or to emigrate, their employment or the possibility of re-employment is a measure of punishment for applicants.

Thus, restrictions on freedom of movement and free choice of residence can be imposed both on the status of a person (Brinzac \& Coci, 2018) and on the territory. In general, these areas are grouped as follows:

1) property and things that are in private ownership, as well as the right to land and the inviolability of housing, with forced alienation is possible on legal grounds only for reasons of public necessity (for example, road construction);

2) a border strip with a special regime of its crossing at checkpoints across the state border;

3) nature reserves, which are protected in a special order;

4) regime objects, i.e. archives, vaults, museums, stock exchanges, jewelry and monetary enterprises;

5) territories where a state of emergency has been imposed;

6) territories where martial law has been imposed.

Persons subject to the above restrictions can be grouped as follows:

1) persons against whom precautionary measures are applied during pre-trial and prosecution;

2) sentenced by a court to imprisonment;

3) deprived or restricted in their freedom to examine their health;

4) which are under administrative supervision; 
5) who are on military service or on alternative military service.

Unjustified restrictions can lead to a hopeless situation in which a person may even resort to violent measures as the only means of exercising his or her rights (Greer \& Sokol, 2014). Therefore, in order to avoid conflict situations, it is necessary to ensure legislative control of the state and the desire of the individual to exercise their fundamental freedoms. Such an approach to human rights must objectively lead to a free interpretation of legal provisions concerning respect for human rights and human dignity.

\section{COVID-19 as a Legitimate Ground for Restricting the Right to Freedom of Movement}

The rapid spread of the coronavirus SARS-CoV-2 and thus the subsequent risk to life and the heavy burden on the health care system of victims of Covid-19-induced disease has led governments to impose many restrictions on normal life in all countries throughout the world. The same situation has developed in Ukraine. As mentioned earlier, the restriction of constitutional rights in Ukraine was allowed if there are certain grounds in the cases and under the conditions specified by law.

According to the first part of Art. 33 of the Constitution of Ukraine, everyone who is legally on the territory of Ukraine is guaranteed freedom of movement, except for restrictions prescribed by law.

Thus, the constitutional right to free movement is not absolute and may be limited by the relevant law (Kachur, Protosavitska, Zasukha \& Golovko, 2020).

In this case, and given the current situation in Ukraine and the state's measures to prevent the spread of COVID-19, such a law is the Law of Ukraine "On Protection of the Population from Infectious Diseases" dated April 6, 2000.

Articles 20 and 22 of this Law stipulate the responsibilities of persons who are potentially infected and the measures to be taken against such persons. Such persons, if they pose a real risk of infecting others, are subject to treatment, medical supervision and examination in appropriate health care facilities.

Article 29 of the Law mentioned above regulates the issue of establishing quarantine, during which the necessary preventive, anti-epidemic and other measures, their executors and terms of implementation are approved, temporary restrictions on the rights of individuals and additional responsibilities imposed on them are determined. Article 31 of the same Law defines the institutions (special hospitals, isolators, observers) on the basis of which the necessary examinations of persons who have had reliable contacts with a patient with a particularly dangerous infectious disease, as well as persons with symptoms of such diseases must be passed.

Paragraph 5 of the Resolution of the Cabinet of Ministers of Ukraine "On Prevention of the Spread of Acute Respiratory Disease COVID-19 Caused by SARS-CoV-2 Coronavirus" defines the list of persons who should be sent for the compulsory hospitalization for 14 days to observers (isolators). These are, in particular:

1) persons crossing the state border, except for persons who:

- works at diplomatic missions or consular posts of foreign states, as well as official international missions or organizations accredited in Ukraine, or is a member of the family of such worker; 
- drivers and crew members of freight vehicles, aircraft and ships or river vessels as well as members of train or locomotive crews;

2) persons entering from the Luhansk and Donetsk areas, which are temporarily occupied, or the Autonomous Republic of Crimea and the city of Sevastopol through checkpoints of entry into and exit from such territories, except:

- staff of the Mission of the International Committee of the Red Cross;

- staff of diplomatic missions accredited in Ukraine, in particular, those monitoring the situation and delivering humanitarian aid to the population living in the Luhansk and Donetsk regions, the Autonomous Republic of Crimea and the city of Sevastopol.

At the same time, children under the age of 12 are subject to hospitalization in the observatory (isolator) together with one of the parents, adoptive parents, guardians, trustees and other persons responsible for taking care of them in accordance with the Ukrainian legislation.

Thus, since in accordance with Art. 33 of the Constitution of Ukraine, citizens of Ukraine cannot be deprived of the right to come back to Ukraine at any time, they are obliged to comply with all rules and established security measures, in particular, related to mandatory isolation (observation) given the quarantine imposed emergency regime and implementation of measures aimed at preventing the spread of coronavirus.

At the same time, the resistance of some citizens to undergo forced observation is associated with self-confidence and their irresponsibility for possible irreversible consequences and threats to other citizens within the state. These citizens are insufficiently informed about the places and conditions of mandatory isolation (observation).

It should be emphasized that the restriction of the constitutional right to freedom of movement and free choice of residence in a pandemic is due to the need to ensure a balance between the interests of individual and public health. Individual health is a private law category, but in terms of the implementation of public health measures, the role of the individual associated with the exercise of personal non-property rights in the field of health care, has an impact on public health, which, prevailing, is a public law category. Sometimes the rights of an individual may be subject to legal restrictions due to the need to protect public health.

Such an approach does not contradict to the practice of the ECtHR. The balance of individual and public health interests is reflected in the case law of the ECtHR, in particular in Solomakhin v. Ukraine (ECtHR, 2012). The ECtHR stated that the violation of the applicant's physical integrity could be considered justified by public health considerations and the need to control the spread of an infectious disease in the area (Torre, 2020).

However, in accordance with the Ukrainian legislation, constitutional rights can be restricted only by law. That fact was the reason for the Supreme Court of Ukraine to appeal to the Constitutional Court of Ukraine to declare some provisions of the Resolution of the Cabinet of Ministers of Ukraine "On the establishment of quarantine to prevent spread on the territory of Ukraine of acute respiratory disease COVID-19 caused by coronavirus SARS-CoV-2, and stages of mitigation of anti-epidemic measures" dated May 20, 2020 (Cabinet of Ministers of Ukraine, 2020) as unconstitutional.

The impugned provisions of paragraph 3 of the mentioned Resolution of the Cabinet of Ministers of Ukraine prohibited, in particular, the freedom of movement on the territory of Ukraine. 
The Constitutional Court of Ukraine emphasized that the restriction of constitutional rights and freedoms was possible in cases specified by the Constitution of Ukraine. Such a restriction may be established only by law. Establishing such a restriction by a bylaw contradicts Articles 1, 3, 6, 8, 19, 64 of the Constitution of Ukraine (Constitutional Court of Ukraine, 2020).

This means that limitation of the freedom of movement for the period of quarantine was unconstitutional. Such a limitation would be legitimate only in case it is implemented by law.

\section{Conclusions}

1. The analysis of the Ukrainian legislation gives grounds for a conclusion that the right to freedom of movement should be understood as the right to move on the territory of Ukraine in any direction freely and without the need to obtain any special permits, in any way, at any time, as well as to leave the territory of Ukraine, except for restrictions established exclusively by law. This right is guaranteed by the Constitution of Ukraine and international legal acts,

2. There are some legitimate grounds for the restriction of the right to freedom of movementand free choice of residence. Such restrictions can be imposed both on the status of a person and on the territory. In general, these areas are grouped as follows:

1) property and things that are in private ownership, as well as the right to land and the inviolability of housing, with forced alienation is possible on legal grounds only for reasons of public necessity (for example, road construction);

2) a border strip with a special regime of its crossing at checkpoints across the state border;

3) nature reserves, which are protected in a special order;

4) regime objects, i.e. archives, vaults, museums, stock exchanges, jewelry and monetary enterprises;

5) territories where a state of emergency has been imposed;

6) territories where martial law has been imposed.

Persons subject to the above restrictions can be grouped as follows:

1) persons against whom precautionary measures are applied during pre-trial and prosecution;

2) sentenced by a court to imprisonment;

3) deprived or restricted in their freedom to examine their health;

4) which are under administrative supervision;

5) who are on military service or on alternative military service.

3. To implement restrictions of human rights, in particular, of the right to freedom of movement the measure of the state intervention should be estimated to guarantee the balance between public and private interests.

4. The approach chosen by the Ukrainian legislator while implementing measures aimed at prevention of the spread of coronavirus COVID-19 were not appropriate and unconstitutional. During the pandemic, a fundamental principle of the protection of human rights was violated as constitutional right to freedom of movement was restricted by the Resolution of the Cabinet of Ministers of Ukraine although such restriction could only be implemented by law. 


\section{References}

Anisimova M. (2005). The right to freedom of movement and free choice of residence in Ukraine: history, current state and prospects for development. Zaporozhye: Dikoe Pole, 207 p.

Baranov K., Kozlyuk A. \& Vashkevich A. (2015). Cross-border aspects of freedom of movement: international standards and practical problems on the example of Belarus, Russia and Ukraine. Lviv: Liga-Press, 202 p.

Brinzac V.I. \& Coci A.I. (2018). Assessing the Self-reported Level of Knowledge, of Romanian Parents with 4-12 Year Old Children, on Emergency Behavior. European Journal of Sustainable Development, 7(3), pp. 425-433. Doi: $10.14207 /$ ejsd.2018.v7n3p425

Cabinet of Ministers of Ukraine. (2020). On prevention of the spread of coronavirus COVID-19 in Ukraine: Resolution of the Cabinet of Ministers of Ukraine of March 11, 2020. Retrieved from https://www.kmu.gov.ua/npas/prozapobigannya-poshim110320rennyu-na-teritoriyi-ukrayini-koronavirusu-covid-19

Cabinet of Ministers of Ukraine. (2020). On the establishment of quarantine to prevent spread on the territory of Ukraine of acute respiratory disease COVID-19 caused by coronavirus SARS-CoV-2, and stages of mitigation of anti-epidemic measures: Resolution of the Cabinet of Ministers of Ukraine of May 20, 2020. Retrieved from https://www.kmu.gov.ua/npas/pro-vstanovlennya-karantinu-z-metoyu-zapobigannya-poshirennyu-nateritoriyi-ukrayini-gostroyi-respiratornoyi-hvorobi-covid-19-sprichinenoyi-koronavirusom-sars-covi200520-392

Chekhovich S. (2003). The state of legislative support for the implementation and protection of the right to freedom of movement and free choice of residence in Ukraine. Kyiv: Legal Initiative Foundation, $100 \mathrm{p}$.

Chekhovich S. (2008). Improving the principles of migration regulation processes in the context of constitutional reform. Strategic priorities, 2, pp. 179-184.

Constitutional Court of Ukraine. (2020). Decision of the Constitutional Court of Ukraine in the case on the constitutional petition of the Supreme Court on the constitutionality of certain provisions of the Resolution of the Cabinet of Ministers of Ukraine "On quarantine to prevent the spread of acute respiratory disease COVID-19 caused by coronavirus SARS-CoV-2, and stages event" of August 28, 2020. Retrieved from https://zakon.rada.gov.ua/laws/show/v010p710-20\#Text

Council of Europe. (1968). Protocol № 4 to the Convention for the Protection of Human Rights and Fundamental Freedoms, which guarantees certain rights and freedoms not provided for in the Convention and in the First Protocol thereto. Retrieved from https://www.coe.int/en/web/conventions/full-list/-/conventions/treaty/046

Dinko O. (2003). The content and guarantees of freedom movement of man and citizen in Ukraine: Abstract of PhD Thesis. Kyiv, 18 p.

Greer S.L. \& Sokol T. (2014). Rules for Rights: European Law, Health Care and Social Citizenship. European law journal, 20(1), pp. 66-87. DOI: 10.1111/eulj.12036

Jabłoński M. (2014). Realizacja i ochrona konstytucyjych wolności i praw jednostki w polskim porzadku prawnym. [online] Retrieved from http://www.bibliotekacyfrowa.pl/Content/52906/Realizacja_i_ochrona _konstytucyjnych_praw.pdf

Kachur V., Protosavitska L., Zasukha L. \& Golovko L. (2020). The Role of Legal Culture in Maintaining Social Stability and Countering Separatist Movements: Case of Ukraine. European Journal of Sustainable Development, 9(1), pp. 294-299. Doi: 10.14207/ejsd.2020.v9n1p294

Litins'ka Y.-\& Karpenko O. (2020). Does Self-isolation Violate the Right to Liberty? An Analysis of the European Court of Human Rights' Practice in Light of the Ukrainian Experience. European Journal of Health Law, 27 (4), pp. 368-385. DOI: https://doi.org/10.1163/15718093-BJA10024

Muchnik A. (2003). Commentary on the Constitution of Ukraine. Kiev: Parliamentary Publishing House, 400 p. Lukasheva E. (2001). Human rights. Moscow: Publishing house NORMA, 573 p.

Pogorilko V. (2006). Constitutional law of Ukraine. Academic course. Kyiv: Publishing House "Legal Thought", 800 p.

Stefanchuk R. (2008). Personal intangible rights of individuals (concepts, content, system, features of implementation and protection). Kyiv: KNT, 626 p.

Sukhanova D. (2009). Features of the use of presumptions in the field of human rights. Comparative legal research, 2 , pp. 86- 91 .

The European Court of Human Righ. (2012). Solomakhin v. Ukraine (Application no. 24429/03) of March $15,2012$. Retrieved from http://health-rights.org/index.php/cop/item/case-of-solomakhin-v-ukraine 
Torre F. (2020). The Constitution under pressure in the times of Coronavirus. Biolaw journal, 1, pp. 61-69.

United Nations. (1996). International Covenant on Civil and Political Rights. Retrieved from https://www.ohchr.org/en/professionalinterest/pages/ccpr.aspx

Vansweevelt T. \& Dewallens F. (2020). Healthcare law and the COVID-19 outbreak in Belgium. Medicine and Law, 39 (2), pp. 131-150.

Vasilieva T. (2010). Migration policy, citizenship and status of foreigners in the countries of the western democracy (comparative legal research): Habilitat. Doctor Thesis. Moscow, $469 \mathrm{p}$.

Verkhovna Rada of Ukraine. (1991). On the State Border of Ukraine: Law of Ukraine of November 4, 1991. Retrieved from http://zakon4.rada.gov.ua/laws/show/1777-12

Verkhovna Rada of Ukraine. (1994). On ensuring the sanitary and epidemiological well-being of the population: Law of Ukraine of February 24, 1994 Retrieved from https:// zakon.rada.gov.ua/laws/show/4004-12\#Text

Verkhovna Rada of Ukraine. (1994). On the Procedure for Leaving Ukraine and Entering Ukraine by Citizens of Ukraine: Law of Ukraine of January 21, 1994. Retrieved from https://zakon.rada.gov.ua/laws/show/385712\#Text

Verkhovna Rada of Ukraine. (1996). Constitution of Ukraine: Law of Ukraine of June 28, 1996 № 254א/96-BP. Retrieved from https://zakon.rada.gov.ua/laws/show/254\%D0\%BA/96- $\% \mathrm{D} 0 \% \mathrm{~B} 2 \% \mathrm{D} 1 \% 80 \#$ Text

Verkhovna Rada of Ukraine. (2000). On protection of the population from infectious diseases: Law of Ukraine of April 6, 2000. Retrieved from https://zakon.rada.gov.ua/laws/show/1645-14\#Text

Verkhovna Rada of Ukraine. (2001). Criminal Code of Ukraine: Law of Ukraine of April 5, 2001. Retrieved from https://zakon.rada.gov.ua/laws/show/2341-14\#Text

Verkhovna Rada of Ukraine. (2003). On Freedom of Movement and Free Choice of Residence: Law of Ukraine of December 11, 2003. Retrieved from https://zakon.rada.gov.ua/laws/show/1382-15\#Text

Verkhovna Rada of Ukraine. (2009). On Border Control: Law of Ukraine of November 5, 2009. Retrieved from https://zakon.rada.gov.ua/laws/show/1710-17\#Text

Verkhovna Rada of Ukraine. (2011). On the legal status of foreigners and stateless persons: Law of Ukraine of September 11, 2011. Retrieved from https://zakon.rada.gov.ua/laws/show/3773-17\#Text

Verkhovna Rada of Ukraine. (2020). On Amendments to Certain Legislative Acts of Ukraine Aimed at Preventing the Occurrence and Spread of Coronavirus Disease (COVID-19): Law of Ukraine of March 17, 2020. Retrieved from https://zakon.rada.gov.ua/laws/show/530-20\#Text

Wilhelm K.E. (2010). Freedom of Movement at a Standstill? Toward the Establishment of a Fundamental Right to Intrastate Travel. Boston University Law Review, 6, pp. 2461-2497. 